Apuntes Universitarios, 2022: 12 (2), abril-junio ISSN: 2304-0335 DOI: https://doi.org/10.17162/au.v12i2.1050

\title{
Satisfacción de los graduados universitarios con la calidad de la educación: aspectos específicos de los métodos de evaluación
}

\author{
University graduates' satisfaction with the quality of education: \\ specifics of assessment methods
}

\author{
Elena I. Grigorieva ${ }^{1 \mathrm{a}}$, Elena Olegovna Kuznetsova ${ }^{2}$, Tatiana Vitaljevna Pushkareva ${ }^{3}$, \\ Anna I. Scherbakova ${ }^{4}$ \\ Russian State Social University, Russian Federation ${ }^{13}$ \\ Russian State Pedagogical University named after A.I. Herzen, Russian Federation ${ }^{2}$ \\ Schnittke Moscow State Institute of Music, Russian Federation ${ }^{4}$ \\ (iD) ORCID ID https://orcid.org//0000-0002-2034-6602 1 \\ ORCID ID https://orcid.org//0000-0001-6301-88982 \\ ORCID ID https://orcid.org//0000-0002-9139-6121 \\ ORCID ID https://orcid.org//0000-0001-7371-7211
}

Recibido: 13 de marzo de 2021

Aceptado: 10 de noviembre de 2021

\begin{abstract}
Resumen
El propósito del artículo es determinar la satisfacción de los graduados universitarios con la calidad de la formación en los programas educativos. La metodología de investigación se basa en las características de la calidad de la educación, que pueden expresarse en determinados indicadores cuantitativos. Tales características medibles incluyen evaluaciones cuantitativas tradicionales del nivel de conocimiento adquirido, indicadores cuantitativos de la demanda de especialistas graduados en el mercado laboral y el grado de satisfacción con la formación de los propios estudiantes. El estudio incluyó a 120 egresados del grupo ampliado de "Estudios culturales y diseño sociocultural" de los años 2018-2020. Se utilizaron los siguientes métodos: métodos de encuesta: cuantitativos (cuestionario) y cualitativos (entrevistas). La metodología propuesta y probada para medir la satisfacción de los egresados universitarios con los programas educativos puede convertirse en la base para el desarrollo de un sistema universitario de seguimiento de la medición de la satisfacción de los egresados universitarios con los programas educativos y un sistema de gestión de la calidad universitaria.
\end{abstract}

Palabras clave: Universidad, educación, estudiantes de posgrado, métodos, práctica investigadora. 


\begin{abstract}
The purpose of the article is to determine the satisfaction of university graduates' with the quality of training in educational programs. The research methodology is based on the characteristics of the quality of education, which can be expressed in certain quantitative indicators. Such measurable characteristics include traditional quantitative assessments of the level of knowledge gained, quantitative indicators of the demand for graduated specialists in the labor market and the degree of satisfaction with the training of the students themselves. The study included 120 graduates of the enlarged group of "Cultural studies and socio-cultural design" of the years 2018-2020. The following methods were used: survey methodsquantitative (questionnaire survey "Factors affecting the satisfaction of graduates quality of higher education"), and qualitative (interviewing). The proposed and tested methodology for measuring the satisfaction of university graduates with educational programs can become the basis for the development of a university system for monitoring the measurement of satisfaction of university graduates with educational programs and a university quality management system.
\end{abstract}

Keywords: University, education, graduate students, methods, research practice.

\title{
Introduction
}

The research practice in studying university graduates' satisfaction with the quality of educational programs has been developing in Russian universities since the 1990s when higher education had begun to be viewed as a product or an educational service. Students have become consumers of this product, and universities have turned into independent subjects of the market system between which competition develops and grows (Bespalova \& Zhirnova, 2015).

Since that time, the assessment of students' and graduates' satisfaction with the quality of educational programs has been gradually becoming a part of intra-university education quality management systems. The first educational quality management system appeared in the People's Friendship University of Russia (RUDN) in 2005 (Filippov \& Puzanova, 2015). The satisfaction of customers-students and graduates-became the system-forming indicator of education quality (Kotova \& Khasanova, 2016). Universities' education quality management system predominantly focuses on international organization quality assessment systems in accordance with which the certification procedure takes place. The reference point most popular in Russia is the ISO 9000:2000 standard (GOST ISO 9000-2001) (Kriukov, 2009). According to the international standards of ISO 9000:2015, customer orientation presents the fundamental principle of creating an effective and productive management system in organizations including universities; so, quality management is aimed at meeting the customers' demands and striving to exceed their expectations and fulfilling this principle calls for assessing and monitoring of consumer satisfaction and taking corresponding action (Rosstandart, 2019). 
Despite quite a long tradition of measuring the evaluation of the quality of obtained education (Vishnevskii \& Narkhov, 2019; Stepanova \& Chernenkaia, 2015), many problems in this sphere remain unresolved, one of such problems being the lack of a well-functioning comprehensive assessment of graduates' satisfaction with education. The search for an optimal model of education quality assessment and monitoring of consumer satisfaction with educational services continues. The aforementioned facts impede the adoption of appropriate management decisions within a university and the development of economic strategies of a university in the foreign market of educational services (Avramkova et al., 2021).

Moreover, the deficit of effective feedback mechanisms in the educational process remains one of the most crucial problems of university education. An essential factor in solving this problem is the choice of pedagogical strategies in favor of students to ensure their actual personal development and professional training sufficient to make them demanded in the labor market and pursue their professional career in the real society (Kennedy, 2016). One of the critical features of the corresponding personality-oriented university pedagogics is the implementation of continuous monitoring of graduates' satisfaction with the quality of training in educational programs (Anufrieva et al., 2020). This research procedure also possesses specific ethical characteristics associated with the observance of students' rights to express their requests and interests considering the content and technology of the obtained knowledge being of vital importance for both their professional and personal growth (Jehanzeb \& Bashir, 2013).

In the light of the context above, it can be affirmed that in the modern world, the problem of university graduates' satisfaction with the quality of educational programs has to be posed and solved in the unity of these four factors-economical, managerial, pedagogical, and ethical-which requires a corresponding correction of the research method which is proposed in the present study.

The calculation of the satisfaction index in general and by factors for the entire sample and different groups of graduates is considered as the basis for compiling a profile of graduate satisfaction lying at the basis of our model for monitoring university graduates' satisfaction with educational programs. These results can be used in advertising and information campaigns. In the course of the admissions campaign, a special emphasis can be put on the professionalism of teachers, disclosing the nomenclature of academic disciplines in each direction of training in greater detail, and providing full information about the order and quality of the educational process organization. The monitoring of graduates' satisfaction with their education has shown that this research procedure is promising for improving the entire organization of university educational activities. It turned out that the students themselves can be considered authoritative 
experts in assessing the effectiveness of the educational process. The written survey data was supplemented by interviewing graduates who showed a deep interest in giving constructive answers to the questions posed.

\section{Methodology}

\section{Design and methods}

A data collection system for monitoring the satisfaction of graduates with the quality of higher education was developed based on a mixed type of research. To collect data, the following methods were used: survey methods - quantitative (questionnaire) and qualitative (interviewing). In this study, we used verification of tools for the validity and adequacy of the research objectives (validation). We used variations of criterion validity to understand how the results obtained for one indicator were consistent with the results obtained for another indicator. To build the model of the relationship between the selected criteria, we used construct validation.

The satisfaction of graduates with the quality of higher education was initially considered in our study as a subjective assessment of the quality of education received by a graduate. To concretize the assessment of graduates, the factors (parameters, criteria) of education were singled out, from which in aggregate this assessment is formed: assessment of the material and technical base; assessment of the management of the educational process; assessment of the professional level of teachers; assessment of the relevance of a set of disciplines; assessment of educational and industrial practices; assessment of conditions for building an individual trajectory of education, self-development, and self-improvement; assessment of the level of psycho-emotional comfort during training (Avramkova et al., 2020; Fatkulin, 2007).

The respondents were also asked to identify three factors that were most important in their opinion or add their own factors. Three parameters of a graduate's self-evaluation allowing making judgments on the education quality evaluation were also identified: evaluation of the level of one's theoretical professional training (self-assessment); evaluation of the level of one's practical professional training (self-assessment); salary expectations; the degree of one's identification with the obtained profession (Miliaeva, 2016; Bobrova, 2018). 


\section{Research procedure and instruments}

The research procedure included the use of a questionnaire in remote access in accordance with the developed method of computer recording and processing of the data obtained in the SPSS program. The questionnaires were compiled by adaptation (modification) based on the tools that were used for similar studies in monitoring graduates' satisfaction with the quality of higher education. After preparing the questionnaires, we discussed their reliability and identified their strengths and weaknesses with other monitoring participants. Based on the results of the discussion, we made adjustments to the questionnaires before starting to collect data. The respondents received a unique e-mail link to the questionnaire, which was posted on docs.google.com (Sivakumar, 2019). The survey «Factors affecting the satisfaction of graduates quality of higher education» included 29 questions that took under 5 minutes to answer and the interview guide included 35 questions with the interviews on them taking about 1 hour on average.

When testing respondents, the ethical principles of respect to the person's dignity and justice were observed. The respondents were guaranteed the protection of personal data, ensuring that the results of the study will be presented in a summary form. The respondents were provided with detailed instructions on the data collection methods, the duration of the study, the aim of the study, as well as the future use of the results.

\section{Statistical analysis}

To interpret the results obtained, we used a correlation model. Self-assessment and the assessment of the educational process by factors were carried out by the respondents on a metric three-point scale ranging from (1) low, to (2) average, to (3) high mark allowing us to calculate correlations, use the average value as evaluation by parameters, and calculate the satisfaction index. Statistical analysis of the experimental results obtained when comparing two empirical distributions according to the Pearson $\chi 2$ test was carried out using the SPSS statistical software package.

The correlation model included the identification of the following correlations: the dependence of the level (high, low) of education on other factors of the educational process (material and technical base, level of teaching, etc.); establishing the ranks of the greatest (least) given dependence; dependence of the degree of relevance of disciplines and assessment of the level of education; dependence of identification with the profession on the level of theoretical, practical training, industrial practice; dependence of the selected factors of the quality of the 
educational process and the assessment of the level of education; desire to choose the same educational institution from satisfaction with education.

\section{Results}

\section{Satisfaction index}

The pilot study included 120 graduates of the enlarged group of specialties 51.03 .00 "Cultural studies and socio-cultural design" of the years 2018-2020. The gender composition of the sample was as follows: female respondents represented $66.7 \%$ of the sample and male respondents composed $33.3 \%$ of it. The sample composition by the levels of the obtained education: Bachelor's graduates $-61.5 \%$; Master's graduates $-17.9 \%$; graduates of both Bachelor's and Master's degrees of the university $-20.5 \%$. The composition of the sample by the forms of education: full-time $-53.8 \%$; extramural $-43.6 \%$; full-time and part-time $-2.6 \%$. Sample composition based on tuition: students receiving free education (budget-based education) - 87.2\%; students paying tuition (contract-based education) - 12.8\%. Sample composition by the region of residence: Moscow and the Moscow region - 94.9\%; regions of the Central Federal District $-2.6 \%$, regions of the Northwestern Federal District $-2.6 \%$.

The index of the respondents' satisfaction with education in the pilot study was $73 \%$. Considering satisfaction with the quality of educational programs by individual parameters, the highest scores were received by the parameters of "the development of interest and professional motivation" (satisfaction index equaled 87\%) and "the level of teaching" (satisfaction index equaled $79 \%$ ) and the lowest results were obtained in the parameters of "educational and production practice" (index $-60 \%$ ) and "management" (index $-64 \%$ ). Considering that the pilot study results showed that $68 \%$ of graduates were generally satisfied with their professional training, improvement of the work of practice bases is quite achievable and does not require excessive managerial effort (Table 1). 
Table 1

Satisfaction index by parameters (in \%)

\begin{tabular}{lcccc}
\hline \multicolumn{1}{c}{ Parameters } & Bachelor's degree & $\begin{array}{c}\text { Master's } \\
\text { degree }\end{array}$ & $\begin{array}{c}\text { Bachelor's and } \\
\text { Master's degrees }\end{array}$ & Overall \\
\hline Overall evaluation of education & 56 & 81 & 87 & 73 \\
Material and technical base & 74 & 86 & 71 & 75 \\
Management & 57 & 76 & 75 & 64 \\
Teaching & 72 & 95 & 88 & 79 \\
Relevance of disciplines & 67 & 90 & 79 & 74 \\
Identification with profession & 64 & 81 & 75 & 69 \\
Theoretical training & 68 & 86 & 79 & 74 \\
Practical training & 67 & 71 & 71 & 68 \\
Practice & 57 & 57 & 71 & 60 \\
Conditions for self-realization & 74 & 81 & 71 & 74 \\
Psycho-emotional comfort & 69 & 86 & 79 & 74 \\
Electronic environment & 72 & 86 & 62 & 72 \\
Interest & 84 & 95 & 88 & 87 \\
\hline
\end{tabular}

To analyze satisfaction with the educational process in general and by individual factors, we conducted a comparison of the satisfaction index in Bachelor's and Master's graduates, graduates who received their education for free and paying the tuition, and graduates who received their education in various forms and different directions of training (Bolotov \& Efremova, 2007; Eliseeva, 2013). Overall, it can be stated that the satisfaction index was higher in Master's graduates and graduates of both Bachelor's and Master's degrees of the university compared to Bachelor's graduates. The satisfaction index was also higher in graduates who received their education tuition-free compared to those who paid for it. Finally, the satisfaction index was significantly higher in extramural students compared to full-time students (Ermakova \& Nikulina, 2017).

It did not appear possible to use the satisfaction index as a guide for the intra-university training quality assessment by comparing the satisfaction index in different directions of training since the differences in the number of budget-based and contract-based places for applicants, the different forms of training, and other factors. The calculation of the satisfaction index by factors and in general for different groups of graduates is viewed as the basis for creating a profile of graduate satisfaction lying at the basis of our model for monitoring university graduate satisfaction with educational programs. 


\section{If you had to enroll in a university again, would you choose the same educational institution?}

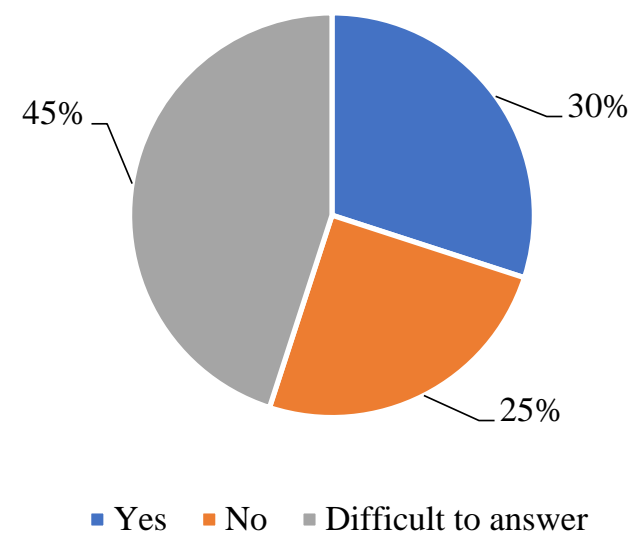

Figure 1

"If you had to enroll in a university again, would you choose the same educational institution?"

An interesting result in the satisfaction index was observed in the three respondent groups that formed according to the answer to the question "If you had to enroll in a university again, would you choose the same educational institution?" (Figure 1). The satisfaction index of the respondents who answered "yes" (about $30 \%$ of the sample) was $86 \%$, of those who answered "no" ( $25 \%$ of the sample) - 55\%, and of those who answered "difficult to answer" ( $45 \%$ of the sample) $-75 \%$. This question has to be reformulated in the monitoring in a more specific fashion, without the subjunctive mood to differentiate these groups more clearly (for instance, "Will you recommend this university to your acquaintance to receive higher education in?").

Overall, based on the analysis of the results of this question, we can assume that the condition ensuring the highest graduate loyalty which allows them to recommend the university to their friends and acquaintances (that is, the condition for the launch of the "word of mouth") was reaching the graduate satisfaction index of $86 \%$. This assumption is also supported by the fact that approximately the same satisfaction index (87\%) was demonstrated by the group of graduates of both the Bachelor's and Master's degrees who had already demonstrated a high degree of loyalty to the university. The formation of a holistic loyalty program is considered by modern researchers as a factor in the university competitiveness (Grace \& Kim, 2008) and student loyalty is becoming the basis for the financial well-being of universities in the modern world (Reznik \& Savenkova, 2009). 


\section{Satisfaction index}

The overall satisfaction index of those surveyed in the pilot study of graduates is 73 percent. If we consider satisfaction with the quality of educational programs by individual factors, then the parameters ("development of interest and professional motivation" (the satisfaction index is 87\%) and "the level of teaching" (the satisfaction index for this parameter is $79 \%$ ) received the highest ratings, and the lowest - parameters "educational and industrial practice" (index 60\%) and "management" (index 64\%).

To analyze satisfaction with the educational process in general and by factors, a comparison was made of the satisfaction index among graduates of bachelor's and master's degrees, graduates who received education on a budgetary and contractual basis, among graduates of different forms of education, as well as areas of training.

In general, the satisfaction index is higher among graduates of the master's degree, as well as bachelor's and master's degrees, compared with graduates of the bachelor's degree. The satisfaction index is higher among graduates who received education on a budgetary basis than among those who studied on a contract basis. The satisfaction index is significantly higher among graduates of the correspondence department in comparison with full-time students.

Table 2

Satisfaction index by parameters (percentage)

\begin{tabular}{ll}
\hline Parameters & Total \\
\hline Assessment of education in general & 73 \\
Material and technical base & 75 \\
Management & 64 \\
Teaching & 79 \\
Relevance of disciplines & 74 \\
Identification with the profession & 69 \\
Theoretical training & 74 \\
Practical training & 68 \\
Practice & 60 \\
Conditions for self-realization & 74 \\
Psycho-emotional comfort & 74 \\
Electronic environment & 72 \\
Interest & 87 \\
\hline
\end{tabular}


It is not possible to use the satisfaction index as a benchmark for an intra-university assessment of the quality of training by comparing the satisfaction index in different areas of training. A significant factor here may be a different number of budget and contract places, forms of training, and other factors. The calculation of the index of satisfaction by factors and, in general, for different groups of graduates is considered as the basis for compiling a profile of graduate satisfaction, which is the basis of our model for monitoring the satisfaction of a university graduate with educational programs.

Foreign higher education institutions separate the objective and subjective education quality indicators and evaluate both the demand for graduates in society and the actual perception of students of their educational experience at the university (Ginsburg, 1991; Munteanu et al., 2010). In the course of the study, we compiled two significance rankings of the satisfaction factors, the first one reflects the direct evaluation provided by the respondents and the second demonstrates their indirect evaluation which ends up being more objective. The first rating contains the factors that were highlighted by the respondents in their answers to the direct question: "What factors, in your opinion, play the most important role in achieving a high quality of education at a university? Please select three options".

1. The professional level of teachers (32).

2. Relevance of the content of academic disciplines (26).

2. Educational process management (19).

3. Practical professional training (16).

4. The development of interest and professional motivation (15).

5. Psycho-emotional comfort (14).

6. Educational and production practice (11).

7. Theoretical and practical training (11).

8. Conditions for personal improvement (11).

9. Material and technical support (10).

10. The development of the electronic educational environment (3).

The leading positions were occupied by the parameters of "The professional level of teachers", "Relevance of the content of academic disciplines", and "Educational process management". Now, in the second significance ranking of satisfaction factors (indirect evaluation by the respondents), the factors were placed in order of the level of correlation with 
the respondents' overall assessment of education. The absolute values of correlation coefficients were also provided to allow grouping the education quality factors according to the degree of influence on the overall assessment of the quality of education. The pilot study did not reveal strong and very strong correlations between the parameters of the general and specific evaluation. Therefore, the factors can be grouped by two degrees of significance: weak and averagee.

1. The professional level of teaching.

2. Psycho-emotional comfort.

3. Practice.

4. The relevance of the academic disciplines.

5. Management.

6. Theoretical training.

7. Interest.

8. Practical training.

9. Conditions for self-realization.

10. Electronic environment.

11. Material and technical base.

The highest values of the coefficient of correlation with the variable of "General assessment of the quality of education" were demonstrated by the variables "Assessment of psycho-emotional comfort", "The level of professionalism of teachers", "Practice", and "Relevance of academic disciplines". In both rankings, the first place was occupied by the factor of the professionalism of teaching. However, there were also noticeable discrepancies in the rankings compiled based on the respondents' direct and indirect evaluation. The second rating provides a more realistic picture of the formation of graduates' real satisfaction with educational programs and its results can be used in intra-university quality management.

\section{Data on the graduates' employment and professional identification development factors}

The fact of employment in the obtained profession is viewed by researchers as one of the main indicators of university graduates' satisfaction with educational programs (Sandler et al., 2018; Sushhenko et al., 2019; Abramov et al., 2016). The pilot study demonstrated the following results: $25 \%$ of the respondents were employed in the obtained profession, $40 \%$ of the respondents worked in a different profession, and 35\% of them were unemployed (Figure 
2). The dynamic of this parameter across the years can become a guideline for the intrauniversity education quality management system, as well as a method of the advertising selfpresentation of the university on the educational services market.

\section{Are you currently employed?}

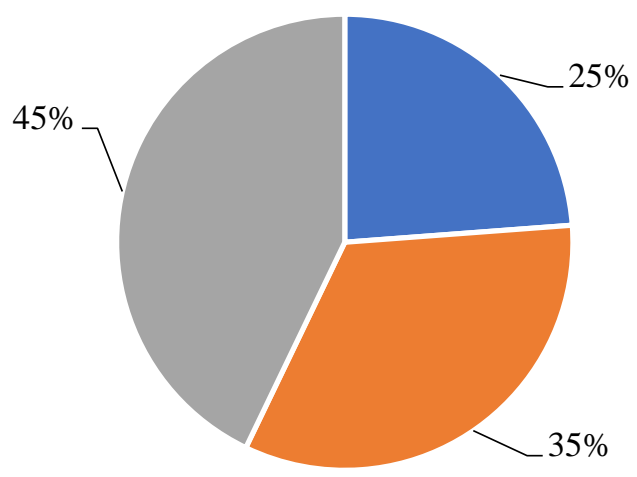

- Yes, I work in my specialty $\quad$ "Yes, I work in a different specialty $\quad$ " Not employed

Figure 2

The graduates' employment

In our opinion, an important factor in graduates' readiness to work in their specialty in the long-term perspective is presented by the level of their identification with the profession indicated in the higher education diploma. According to the pilot study results, a high level of identification with the obtained profession was experienced by $17.9 \%$ of the respondents, the average degree of identification was demonstrated by $71.8 \%$, and the low level of identification was observed in $10.3 \%$. What is curious is that professional identification correlated with the level of the graduates' theoretical training.

To ensure a deeper understanding of the results, in addition to the acquired quantitative results, the pilot study involved qualitative sociological methods - open survey questions and interviewing. Overall, the advantages and disadvantages stated by the graduates in the open questions revolved around the previously identified factors and indicators except for one: several respondents argued that universities need to work on graduates' employment.

\section{Discussion}

Based on the study results, all the factors of the quality of professional educational programs that we identified have an impact on the satisfaction of graduates. Therefore, in the 
future, when conducting monitoring, it is necessary to measure the influence of each factor on the graduate's satisfaction with professional educational programs (Gopal et al., 2021). As in the research of Sandler et al. (2018), it can be proposed that the factors that form the graduates' satisfaction with professional programs: material and technical base; educational process management; the professional level of teaching; relevance of the set and content of disciplines; educational and production practice; conditions for self-development and self-improvement; conditions for the development of interest and professional motivation; psycho-emotional comfort; electronic educational environment; all of this is compared with the study of Anufrieva et al. (2020).

This study wanted to complement the list of factors that can influence the satisfaction of graduates as much as possible. Therefore, by asking respondents to evaluate the significance of each factor or add their own, we were able to obtain data that corresponded to our expectations. One of the main indicators of the satisfaction of university graduates with educational programs is employment in the profession they acquired, as in Sushhenko et al., (2019); Abramov et al. (2016), which was confirmed by our results.

Based on the calculation of the satisfaction index of graduates who graduated from both the Bachelor's and Master's level at the university in question (and thereby showed the maximum loyalty to the university), the target value of the graduate satisfaction index was obtained. We considered the calculation of the satisfaction index by factors and in general for different groups of graduates as the basis for compiling a profile of graduate satisfaction, which underlies our model for monitoring the satisfaction of a university graduate with educational programs, as in the study of Ginsburg (1991). We believe that our research, conducted at a Russian university, has confirmed the international trend aimed at separating objective and subjective indicators for assessing the quality of education. In foreign higher education institutions, objective and subjective indicators of the quality of education are divided. Both the demand for graduates in society and the actual perception of students' educational experience at a university are assessed (Munteanu et al., 2010).

In the course of the pilot study, two significance rankings of satisfaction factors were compiled. The first ranking demonstrates the direct evaluation provided by the respondents which can be used in advertising and information campaigns in the educational services market (Miliaeva, 2016). The second ranking reflects the indirect evaluation providing a more realistic picture of the actual impact of different factors on the formation of graduates' satisfaction with educational programs and its results can be used in intra-university quality management (Blankenship, 2011). 
Summarizing the results, in both rankings, the first place was occupied by the factor of the professionalism of teaching. However, there were also noticeable discrepancies in the rankings compiled based on the respondents' direct and indirect evaluation (Avramkova et al., 2020). The second rating provides a more realistic picture of the formation of graduates' real satisfaction with educational programs and its results can be used in intra-university quality management.

Researchers are actively paying attention to the development of quality management in universities. In particular, in the works by Shatskaya (2021), the most important tool for measuring key indicators in education is their continuous monitoring. Monitoring in education is "a system for collecting, processing, storing, and disseminating information about an education system or its elements, focused on information management support, which allows one to judge the state of an object at any time and can provide a forecast of its development" (p. 447). Such monitoring allows evaluating the work of each teacher and helps them develop professionally. In turn, as the results of our study show, the introduction of such an assessment affects graduates' satisfaction with the quality of university educational programs.

The open questions included in the survey, as well as the interviews conducted with the graduates, make it possible to obtain a wider range of subjective assessments of professional programs. Nevertheless, most of the feedback revolved around the previously identified factors and indicators (Simsek, Turan \& Simsek, 2017). The introduction of qualitative studies in the university graduates' satisfaction monitoring system allows one to "depressurize" the quantitative methodology ensuring the possibility of quickly tracking and taking into account new factors and circumstances that arise in the social reality and university life and may require appropriate comprehension and response strategies (Munteanu et al., 2010). Moreover, the opportunity for graduates to give anonymous feedback on the quality of education in the university has a positive psychological effect: overall, the expressed positive and negative emotions normalize the consumer's evaluation and are favorable for the existence of the university in the educational services market (Blankenship, 2011).

Limitations relate to the fact that the data on the skills and knowledge of students is sparse and has limited temporal coverage and even less is known about how the performance of students with respect to these outcomes has changed over time (O'Donovan, 2017). Also it is necessary to take into account the psychological characteristics of students, as well as obstacles that often arise in the learning process. The results obtained differ from the ongoing studies due to the introduced learning satisfaction index as an integral indicator, which makes it possible to carry out a multivariate analysis of the educational process and an overall 
assessment of the real quality of university training based on the diversity of the conditions and characteristics of university activities.

\section{Conclusion}

The results of the monitoring carried out allow us to conclude that there are real prerequisites for the further development of the university not so much due to additional material and human resources, but due to the optimization of the organization of the entire educational process thanks to a well-thought-out system of interconnections of various specialists without infringing on the rights and excessive production overload of all university employees. The system built in this way should include the following interrelated functional blocks: the material and technical base of the university, the teaching staff, administrative and managerial personnel, students, financial and legal support. If one of these blocks operates without communication with the others, imbalances arise in the organization of the university's work, which significantly negatively affects its effectiveness.

\section{References}

Abramov, R. A., Pronina, I. V., \& Khalatenkova, E. Y. (2016). Increasing the professional demand for university graduates. The Education and Science Journal, 10 (139), 91-106. https://doi.org/10.17853/1994-5639-2016-10-91-106

Anufrieva, N. I., Volkov, L. V., Aralova, E. V., Kolomyts, O. G., \& Myagkova, E. V. (2020). Environmental education: nurturing of the humanistic orientation of a personality. Universal Journal of Educational Research, 8 (11): 5529 - 5535. https://doi.org/10.13189/ujer.2020.081156

Avramkova, I. S., Anufrieva, N. I., Kamyanets, A. V., Kuznetsova, E., \& Scherbakova, A. I. (2020). Socio-ecological foundations of intercultural communication studies of in the conditions of globalization. Revista Inclusiones, 7, Especial, 177-191. https://revistainclusiones.org/index.php/inclu/article/view/1154

Avramkova, I. S., Anufrieva, N. I., Kamyanets, A. V., Kuznetsova, E. O., \& Scherbakova, A. I. (2021). Monitoring studies of university graduates' satisfaction with the quality of education: the main approaches. Revista on line de Politica e Gestão Educacional, 25 (1), 638-653. https://periodicos.fclar.unesp.br/rpge/article/view/15004

Bespalova, E. D., \& Zhirnova, E. A. (2015). The quality of education through the eyes of students. Reshetnevskie chteniia, 2, 463-465. https://elibrary.ru/contents.asp?issueid=1523448 
Blankenship, M. (2011). How social media can and should impact higher education. Education Digest, 76 (7): 39-42. https://eric.ed.gov/?id=EJ919052

Bobrova, T. A. (2018). Sovremennaia sistema vysshego obrazovaniia Rossiiskoi Federatsii: osnovnye problemy i puti ikh resheniia [Modern system of higher education in the Russian Federation: the main problems and the ways to solve them]. Molodoi Uchenyi, 45 (231), 127-130. https://moluch.ru/archive/231/53422/

Bolotov, V. A., \& Efremova, N. F. (2007). Sistema otsenki kachestva obrazovaniia: Uchebnoe posobie [The system for assessing the quality of education: Study guide]. Moscow: Logos.

Eliseeva, E. N. (2013). Otsenka udovletvorennosti potrebitelei obrazovatelnykh uslug na fakultete upravleniia [Assessment of satisfaction of consumers of educational services at the Faculty of Management]. Bulletin of the Chelyabinsk State University, 3 (294), 107-110. https://cyberleninka.ru/article/n/otsenka-udovletvorennosti-potrebiteleyobrazovatelnyh-uslug-na-fakultete-upravleniya

Ermakova, Z. H. A., \& Nikulina, I. U. N. (2017). Kachestvo obrazovaniia s pozitsii potrebitelei obrazovatelnykh uslug vuza [The quality of education from the perspective of consumers of educational services of a university]. Creative Economy, 11 (7), 726-735. https://cyberleninka.ru/article/n/kachestvo-obrazovaniya-s-pozitsii-potrebiteleyobrazovatelnyh-uslug-vuza

Fatkulin, A. A. (2007). Sovremennoe obrazovanie: upravlenie, kachestvo, innovatsii: Uchebnoe posobie [Modern education: management, quality, innovation: study guide]. Vladivostok: Publishing house of the Far Eastern State Technical University.

Filippov, V. M., \& Puzanova, Z. V. (2015). Quality of education: the possibilities of new approaches to assessment. Theory and practice of social development, 24, 12-15. https://cyberleninka.ru/article/n/kachestvo-obrazovaniya-vozmozhnosti-novyhpodhodov-k-otsenke

Ginsburg, M. B. (1991). Understanding Educational Reform in Global Context: Economy, Ideology, and the State. New York: Routledge.

Gopal, R., Singh, V. \& Aggarwal, A. (2021) Impact of online classes on the satisfaction and performance of students during the pandemic period of COVID 19. Education and Information Technologies. https://doi.org/10.1007/s10639-021-10523-1

Grace, B. Y., \& Kim, J. -H. (2008). Testing the mediating effect of the quality of college life in the student satisfaction and student loyalty relationship. Applied Research in Quality of Life, 3 (1), 1-21. https://doi.org/10.1007/s11482-008-9044-8

Jehanzeb, K. \& Bashir, N.A. (2013). Training and Development Program and its Benefits to Employee and Organization: A Conceptual Study. European Journal of Business and Management, 5 (2), 243-253. https://www.dcvmn.org/IMG/pdf/3947-5999-1-pb.pdf

Kennedy, M. M. (2016). Parsing the practice of teaching. Journal of Teacher Education, 67, 617. https://doi.org/10.1177/0022487115614617 
Kotova, S. S., \& Khasanova, I. I. (2016). The quality of the university educational process through the eyes of students. The Education and Science Journal, 9 (138), 43-61. https://doi.org/10.17853/1994-5639-2016-9-43-61

Kriukov, D. O. (2009). Education quality management system: concept, relevance, basic models and global trends. Psychology. Sociology. Pedagogy, 2 (1), 107-114. https://cyberleninka.ru/article/n/sistema-menedzhmenta-kachestva-obrazovaniyaponyatie-aktualnost-osnovnye-modeli-i-mirovye-tendentsii

Mikhalkina, E. V., \& Gerasimova, O. Y. (2019). Satisfaction of university graduates with the quality of education in the context of digitalization. State and municipal management. Scholar notes, 4, 76-84. https://doi.org/10.22394/2079-1690-2019-1-4-76-84

Miliaeva, L. G. (2016). Analiz uspeshnosti trudoustroistva vypusknikov vuzov v usloviiakh kompetentnostnogo podkhoda [Analysis of the success of the employment of university graduates in the context of the competency-based approach]. Upravlenie chelovecheskimi resursami. Sbornik nauchnykh trudov. Novosibirsk: Novosibirsk State University of Economics and Management, 2.

Munteanu, C., Ceobanu, C., Bobâlca, C., \& Anton, O. (2010). An analysis of customer satisfaction in a higher education context. International Journal of Public Sector Management, 23 (2), 124-140. https://doi.org/10.1108/09513551011022483

O'donovan, B. (2017). How student beliefs about knowledge and knowing influence their satisfaction with assessment and feedback. Higher Education, 74 (4), 617-633. https://doi.org/10.1007/s10734-016-0068-y

Reznik, G., \& Savenkova, Y. (2009). Formation of a loyalty program as a factor in the competitiveness of a university. Problems of management theory and practice, 2, 8392.

Rosstandart. (2019). Natsionalnyi standart Rossiiskoi federatsii sistemy menedzhmenta kachestva. Osnovnye polozheniia i slovar [National standard of the Russian Federation for quality management system. Fundamentals and vocabulary]. Moscow: Standartinform. http://docs.cntd.ru/document/1200124393

Rusanova, A. A. (2005). Udovletvorennost kak pokazatel kachestva obrazovaniia v sovremennom vuze (iz opyta konkretnogo sotsiologicheskogo issledovaniia) [Satisfaction as an indicator of education quality in a modern university (from the experience of a specific sociological study)]. Novosibirsk: Novosibirsk State Technical University. $\quad$ https://cyberleninka.ru/article/n/udovletvorennost-kak-pokazatelkachestva-obrazovaniya-v-sovremennom-vuze-iz-opyta-konkretnogosotsiologicheskogo-issledovaniya

Sandler, D. G., Sushchenko, A. D., Kuznetsov, P. D., \& Pechenkina, T. E. (2018). Trudoustroistvo vypusknikov i ego sviaz s kachestvom vysshego obrazovaniia [Employment of graduates and its relationship with the quality of higher education]. University management: practice and analysis, 22 (3), 73-83. 
https://cyberleninka.ru/article/n/trudoustroystvo-vypusknikov-i-ego-svyaz-skachestvom-vysshego-obrazovaniya

Shatskaya, I. (2021). Assessment of higher education organizations' involvement in the process of scientific and technological development. Laplage Em Revista, 7 (2), 444-448. https://doi.org/10.24115/S2446-6220202172766p.444-448

Shlykov, G. P. (2008). Sistema menedzhmenta kachestva universiteta [University quality management system]. Moscow: "NTK "Trek" Publishing House.

Simsek, U., Turan, I., \& Simsek, U. (2017). Social studies teachers "and teacher candidates" perceptions on prompt feedback and communicate high expectations. PEOPLE: International Journal of Social Sciences, $3 \quad$ (1), 332, 345. https://www.grdspublishing.org/index.php/people/article/view/411

Sivakumar, R. (2019). Google form in education. Journal of Contemporary Educational $\begin{array}{llll}\text { Research and } & \text { Innovations, } & 9 & \text { (1): }\end{array}$ http://jceri.com/p_issues.php?issue=1\&year=2019

Stepanova, M. M., \& Chernenkaia, L. V. (2015). Student opinion poll as a tool for assessing customer satisfaction with the quality of education in the "Linguistics" master's degree program. St. Petersburg State Polytechnical University Journal, 4 (232), 175-181. https://doi.org/10.5862/JHSS.232.21

Sushhenko, A. D., Kuznetsov, P. D., \& Pechenkina, T. E. (2019). Measuring satisfaction with higher education among financially successful and unsuccessful graduates. Theory and $\begin{array}{lllll}\text { practice of social development, } 10 & \text { (140), }\end{array}$ https://doi.org/10.24158/tipor.2019.10.4

Vasileva, E. I. U. (2008). Sistemnyi monitoring kachestva obrazovatelnoi sredy vuza [Systemic monitoring of the educational environment of the university (Northern state medical university)]. Universitetskoe upravlenie: praktika $i$ analiz, 3 (55), 2008. https://www.umj.ru/jour/article/view/809?locale=ru_RU

Vishnevskii, Y. R., \& Narkhov, D. Y. (2019). Paradoxes of modernization of higher education: the results of 20 years of monitoring in the Sverdlovsk region. RUDN Journal of Sociology, 19 (2), 289-301. https://doi.org/10.22363/2313-2272-2019-19-2-289-301

Volovskaia, N. M., \& Pliusnina, L. K. (2015). Vnutrennii sotsiologicheskii monitoring kachestva obrazovatelnoi deiatelnosti vuza [Internal sociological monitoring of the quality of educational activities of a university]. Theory and Practice of Social Development, 24, 16-18. https://cyberleninka.ru/article/n/vnutrenniy-sotsiologicheskiymonitoring-kachestva-obrazovatelnoy-deyatelnosti-vuza 